\title{
Pre-Harvest Application of Salicylic Acid and Propyl Gallate to Preserve Postharvest Quality of Ber (Ziziphus maurtiana Lamk) Fruits cv Banarasi Karaka
}

\author{
Deepti Shrivastva*, Akhilesh Kumar Pal, Surendra Prasad Singh and Kalyan Barman
}

\author{
Department of Horticulture, Institute of Agricultural Sciences, \\ Banaras Hindu University, Varanasi, India \\ *Corresponding author
}

\begin{tabular}{l} 
K e y w o r d s \\
Pre-harvest, \\
Salicylic acid, \\
Propyl gallate, Ber, \\
Quality parameters, \\
Storage \\
\hline Article Info \\
$\begin{array}{l}\text { Accepted: } \\
\text { 22 March } 2020 \\
\text { Available Online: } \\
\text { 10 April } 2020\end{array}$ \\
\hline
\end{tabular}

\begin{abstract}
A B S T R A C T
Ziziphus maurtiana Lamk, is commonly known as Indian jujube, is an underutilized fruit and native to India. Fruits are small, round to oblong shaped fruits, with thin and glossy skin. The ber fruits contain have antioxidant, anti-flammatory and antibacterial properties. Ber fruits deteriorate rapidly after harvest and can only be stored for 2-4 days. Therefore, the present study was conducted to extend the storability and preserve the ber quality during storage at ambient conditions. An experiment was conducted to study the effect of pre-harvest application of salicylic acid (200, 400, $600 \mathrm{ppm})$ and propyl gallate (150, 300 and 450) ppm on storage quality of ber cv Banarasi Karaka. Fruits of uniform in size were harvested at physiological maturity stage (pea, marble and 15 days before harvesting). Treated fruits were packed in CFB and boxes stored at room temperature. Stored fruit were evaluated after 0, 2, 4, 6 and 8 days. The maximum retention of fruit quality attributes were recorded in SA (600 ppm) TSS, acidity, Vitamin C and total sugar which was followed propyl galalte $(450 \mathrm{ppm})$ treated fruits. Both TSS, ascorbic acid and total sugar showed similar trends of increase up to $6^{\text {th }}$ days of storage followed by a decrease. However, acidity decreased continuously with enhancement of storage period. At the end of the storage, maximum TSS, total acidity, ascorbic acid and total sugars were noted under salicylic acid $(600 \mathrm{ppm})$ treated fruits, followed by fruits treated with propyl gallate $(450 \mathrm{ppm})$. Studies revealed that salicylic acid $(600 \mathrm{ppm})$ treatment have potential to maintain ber fruit maintained quality up to 8days of storage.
\end{abstract}

\section{Introduction}

In Indian, the arid zone covered the around $12 \%$ of country geographical are occupying 31.8 million hectares. Ber (Zizyphus mauritiana Lamk.) is also known as Indian jujube, it is called king of arid zone and also as poor man' $\mathrm{s}$ apple and belong to family
Rhamnaceae. The area under cultivation with this fruit 5 million hectare with an annual production 6.3 MT (NHB, 2017). The ripe ber fruit have great medicinal value and support to blood pressure. lowering aid stomach and diarrhea infection (Dalal et al., 2019) and pulp has contained high sugar content (Sucrose, glucose fructose and starch) which 
provide energy and also contain many amino acids like, glutamic acid, aspartic acid serine and threonine (Bal, 1981). It also rich in calorific value and ascorbic acid in comparison to apple and orange and also rich in calcium, phosphorus and protein (Jawanda and Bal 1978). The genus Ziziphus has around 170 species (Islam and Simmons, 2006), of which 17 are native of India (Watt, 1883; Bailey, 1947; Singh et al., 2000). It is an ideal fruit crops to be grown in the arid and semi-arid zones of northern India, because of its very low irrigation requirement in the hot and dry months, particularly in May and June, when it sheds its leaves and enters into a period of dormancy. Due to high economic returns, improved budded varieties of ber are being cultivated on a commercial scale in Punjab, Haryana, Rajasthan and Uttar Pradesh. It thrives well even under adverse conditions, viz., salinity, drought and waterlogging.

Ber fruits are highly perishable in nature and cannot be stored for long periods under ambient conditions (Salunkhe and Kadam, 1995).This concept to growers to sell their produce in the local market at a low price. Therefore, it is need of time to enhance shelf life of ber fruits in order to make its cultivation profitable to growers through use of chemicals. Propyl Gallate is a phenolic antioxidant widely used in food, cosmetic and pharmaceuticals.

It is a free radical scavenger and inhibits the germination of seed because not osmotic effect (Chaudhary and Kar, 2008). So it is used as preservative and increased postharvest life of fruits. Salicylic acid (SA), an endogenous plant growth regulator and phenolic compound, which is generates metabolic and physiological responses in plants without affecting their growth and development. It delays the ripening of fruits due to inhibition of ethylene biosynthesis and maintains the postharvest quality of fruits
(Srivastva and Diwedi 2000).Synthesis of SA in plants by glycosylated or methylated. In glycosylated, Glucose conjugation at the hydroxyl group and produces SA glucoside [SA 2-O- $\beta$-D-glucoside] as a major conjugate, while glucose conjugation at the SA carboxyl group produces the SA glucose ester in minor amount. The present investigation was therefore, undertaken Pre-harvest application of salicylic acid and propyl gallate to preserve postharvest quality of ber.

\section{Materials and Methods}

The present investigation entitled the present investigation was therefore, undertaken to Pre-harvest application of salicylic acid and propyl gallate to preserve postharvest quality of ber (Ziziphus maurtiana Lamk) fruits cv Banarasi Karaka, which was carried out at Horticulturist Unit, BHU, Varanasi during 2016-17 and 2017-18. Treated ber fruits of uniform size were harvested at optimum maturity from the trees. The Ber trees were sprayed with salicylic acid @ 200, 400 and 600 ppm and propyl gallate @ 150, 300 and $450 \mathrm{ppm}$, at maturity (pea, marble and 15 days before harvesting) before harvesting. the growth to find out the effect of different treatments on shelf life of ber fruits. The investigation was laid out in CRD (Complete Randomized Design) with three replications. Each replication comprised two-kilogram of fruit. The fruits were analyzed for different chemical attributes like Total soluble solids, acidity, ascorbic acid and total sugar, after 0 , 2, 4, 6 and 8 days of storage.

TSS was determined from the juice extracted from the fresh pulp of fruits. The fruits were taken randomly on each date of data recording. It was measured by digital refractometer. The recorded reading were corrected with the help of temperature correction chart at $20^{\circ} \mathrm{C}$ temperature and expressed as ${ }^{0}$ Brix (AOAC, 2000). 
Titrable acidity was estimated by titrating juice against $0.1 \mathrm{~N}$ sodium hydroxide solution using phenolphthalein as internal indicator and expressed as percent anhydrous citric acid (AOAC, 2000). Ascorbic acid content was determined by titrating the juice against 2, 6dichlorophenol indophenol dye solution to a light pink color which persisted for 15 seconds. Finally, results were expressed as $\mathrm{mg} / 100 \mathrm{~g}$ of fruits (A.O.A.C, 2000). The total sugar content was determined by titrating boiling Fehling's solution $(5 \mathrm{ml} \mathrm{A}+5 \mathrm{ml} \mathrm{B})$ against aliquot using methylene blue as indicator (A.O.A.C., 2000)

\section{Results and Discussion}

The analyzed data presented in Table 1 showed statistically significant differences at $\mathrm{p} \leq 0.05$, effect of treatments, storage period and their interaction on TSS was found nonsignificant in the fruits. The fruits showed TSS (15.39 and $15.80{ }^{0}$ Brix) of both years respectively treated with SA $600 \mathrm{ppm}$ as compared to all the treatments and minimum TSS (13.11 and $13.74{ }^{\circ}$ Brix) recorded in control. The quality of fruits decreased with the enhancement of storage period. At the end of the storage fruits treated with salicylic acid retained maximum fruit quality characters. The enhancement in fruit quality may owe to delay in ripening of fruits through reduction in ethylene biosynthesis and action (Srivastava and Dwivedi, 2000). Similar results were also found in kiwifruit (Zhang et $a l ., 2003)$. The TSS content of fruits increased up to 6 days of storage in all the treatments. However, after8 days of storage there was appreciable decreases in TSS content in all the treated fruits. Similar trend was also noticed by Madhav et al., (2018) in guava fruits. Among all the treatments, salicylic acid (600 ppm) treated fruits noted were maximum TSS at the end of storage which was closely followed by propyl gallate $(450 \mathrm{ppm})$ treated fruits.
Further, the increases in TSS may be attributed to conversion of starch to sugar during ripening. Higher concentrations of salicylic acid and propyl gallate might have suppressed the catabolic process such as respiration and ethylene production in treated ber fruits, which led to slow increase in TSS. However, decline in TSS content at $8^{\text {th }}$ days of storage might be because of utilization of the primary substrate for respiration (Wills et al., 1980). Karlidag et al., (2009) reveled that salicylic acid treated fruit increased the TSS in strawberry fruits. Salicylic acid had a significant effect on apple in TSS (Shirzadeh and Kazemi, 2012)

The analyzed data presented in Table 2 showed statistically significant differences at $\mathrm{p} \leq 0.05$ effect of treatments, storage period and their interaction on acidity was found non- significant in the fruits. The fruits show acidity ( 0.156 and $0.143 \%)$ of both years respectively treated with SA $600 \mathrm{ppm}$ as compared to all the treatments and minimum acidity $(0.122$ and $0.120 \%)$ recorded in control. The decrease in acidity might be attributed to conversion of acids to sugars and then utilization of it in the respiration process (Pool et al., 1972). Sandbhor and Desai (1991) also reported a gradual decrease in acid content in ber fruit during storage. On $8^{\text {th }}$ day of storage, the lowest acidity was recorded in control while it was highest in salicylic acid (600 ppm) followed by propyl gallate $(450 \mathrm{ppm})$ treated fruits. The maintenance of the higher acidity during storage was due to reduction in respiration rate. The findings of present investigation corroborate the findings of Dastjerdi et al., (2014).The results in this line (Lu et al., 2011) in pineapple. The analyzed data presented in (Table 3) showed statistically significant differences at $\mathrm{p} \leq 0.05$ regarding the effects of treatments, storage periods and their interaction on vitamin $\mathrm{C}$ contents in the fruits. 
Table.1 Effect of salicylic acid and propyl gallate on total soluble solids of ber fruits during storage

\begin{tabular}{|c|c|c|c|c|c|c|c|c|c|c|c|c|}
\hline \multicolumn{13}{|c|}{ TSS ( ${ }^{\mathbf{0}}$ Brix) } \\
\hline \multirow{3}{*}{ Treatments } & \multicolumn{6}{|c|}{2017} & \multicolumn{6}{|c|}{2018} \\
\hline & \multicolumn{6}{|c|}{ Days after storage } & \multicolumn{6}{|c|}{ Days after storage } \\
\hline & $\mathbf{0}$ & $2^{\text {nd }}$ & $4^{\text {th }}$ & $6^{\text {th }}$ & $8^{\text {th }}$ & MEAN & $\mathbf{0}$ & $2^{\text {nd }}$ & $4^{\text {th }}$ & $6^{\text {th }}$ & $8^{\text {th }}$ & MEAN \\
\hline Control & 12.14 & 13.25 & 14.34 & 13.09 & 12.75 & 13.11 & 13.37 & 13.88 & 14.92 & 13.45 & 13.10 & 13.74 \\
\hline (SA,200 ppm) & 12.45 & 13.45 & 14.94 & 15.34 & 13.89 & 14.01 & 13.82 & 14.59 & 15.34 & 15.88 & 14.10 & 14.74 \\
\hline (SA, 400 ppm) & 12.73 & 14.40 & 15.45 & 15.89 & 14.53 & 14.60 & 14.25 & 15.13 & 15.65 & 16.34 & 14.34 & 15.14 \\
\hline (SA, 600 ppm) & 13.27 & 15.73 & 16.33 & 16.65 & 15.00 & 15.39 & 14.55 & 15.65 & 16.44 & 17.28 & 15.12 & 15.80 \\
\hline$(\mathrm{PG}, 150 \mathrm{ppm})$ & 12.28 & 13.60 & 14.77 & 14.88 & 13.32 & 13.77 & 13.66 & 14.20 & 15.15 & 15.70 & 13.77 & 14.49 \\
\hline$(\mathrm{PG}, 300 \mathrm{ppm})$ & 12.54 & 13.92 & 15.28 & 15.45 & 14.10 & 14.26 & 14.15 & 14.80 & 14.50 & 16.14 & 14.67 & 14.85 \\
\hline$(\mathrm{PG}, 450, \mathrm{ppm})$ & 13.17 & 14.98 & 15.72 & 15.90 & 14.45 & 14.84 & 14.45 & 15.31 & 16.20 & 16.90 & 14.80 & 15.53 \\
\hline MEAN & 12.65 & 14.19 & 15.26 & 15.31 & 14.00 & & 14.03 & 14.79 & 15.45 & 15.95 & 14.27 & \\
\hline \multirow[t]{3}{*}{ CD VALUE } & \multicolumn{4}{|c|}{ DAYS } & 0.431 & & & \multicolumn{4}{|c|}{ DAYS } & 0.476 \\
\hline & \multicolumn{4}{|c|}{ TREATMENT } & 0.364 & & & \multicolumn{4}{|c|}{ TREATMENT } & 0.402 \\
\hline & \multicolumn{4}{|c|}{ TREATMENT X DAYS } & N/A & & & \multicolumn{4}{|c|}{ TREATMENT X DAYS } & N/A \\
\hline
\end{tabular}


Int.J.Curr.Microbiol.App.Sci (2020) 9(4): 2914-2923

Table.2 Effect of salicylic acid and propyl gallate on acidity $\%$ of ber fruits during storage

\begin{tabular}{|c|c|c|c|c|c|c|c|c|c|c|c|c|}
\hline \multicolumn{13}{|c|}{ Acidity \% } \\
\hline \multirow[t]{3}{*}{ TREATMENT } & \multicolumn{5}{|c|}{2017} & & \multicolumn{6}{|c|}{2018} \\
\hline & \multicolumn{5}{|c|}{ Days after storage } & & \multicolumn{6}{|c|}{ Days after storage } \\
\hline & 0 & $2^{\text {nd }}$ & $4^{\text {th }}$ & $6^{\text {th }}$ & $8^{\text {th }}$ & MEAN & 0 & $2^{\text {nd }}$ & $4^{\text {th }}$ & $6^{\text {th }}$ & $8^{\text {th }}$ & MEAN \\
\hline Control & 0.134 & 0.125 & 0.119 & 0.116 & 0.114 & 0.122 & 0.125 & 0.122 & 0.120 & 0.116 & 0.112 & 0.120 \\
\hline (SA,200 ppm) & 0.143 & 0.138 & 0.132 & 0.129 & 0.128 & 0.134 & 0.136 & 0.132 & 0.129 & 0.125 & 0.121 & 0.129 \\
\hline (SA, 400 ppm) & 0.154 & 0.149 & 0.144 & 0.141 & 0.139 & 0.146 & 0.144 & 0.141 & 0.138 & 0.132 & 0.129 & 0.137 \\
\hline (SA, 600 ppm) & 0.160 & 0.158 & 0.156 & 0.152 & 0.151 & 0.156 & 0.152 & 0.148 & 0.143 & 0.140 & 0.133 & 0.143 \\
\hline (PG,150 ppm) & 0.140 & 0.135 & 0.130 & 0.128 & 0.127 & 0.132 & 0.132 & 0.129 & 0.125 & 0.122 & 0.118 & 0.125 \\
\hline$(\mathrm{PG}, 300 \mathrm{ppm})$ & 0.147 & 0.143 & 0.139 & 0.137 & 0.135 & 0.140 & 0.140 & 0.136 & 0.133 & 0.128 & 0.124 & 0.132 \\
\hline$(\mathrm{PG}, 450, \mathrm{ppm})$ & 0.157 & 0.154 & 0.151 & 0.150 & 0.148 & 0.152 & 0.148 & 0.145 & 0.140 & 0.134 & 0.130 & 0.139 \\
\hline MEAN & 0.148 & 0.143 & 0.139 & 0.136 & 0.135 & & 0.140 & 0.136 & 0.133 & 0.128 & 0.124 & \\
\hline \multirow[t]{3}{*}{ CD VALUE } & \multicolumn{4}{|c|}{ DAYS } & 0.009 & & & \multicolumn{4}{|c|}{ DAYS } & 0.006 \\
\hline & \multicolumn{4}{|c|}{ TREATMENT } & 0.008 & & & \multicolumn{4}{|c|}{ TREATMENT } & 0.005 \\
\hline & \multicolumn{4}{|c|}{ TREATMENT X DAYS } & N/A & & & \multicolumn{4}{|c|}{ TREATMENT X DAYS } & N/A \\
\hline
\end{tabular}


Table.3 Effect of salicylic acid and propyl gallate on ascorbic acid content of ber fruits during storage

\begin{tabular}{|c|c|c|c|c|c|c|c|c|c|c|c|c|}
\hline \multicolumn{13}{|c|}{ Ascorbic acid (mg/100g) } \\
\hline \multirow[t]{3}{*}{ Treatments } & \multicolumn{5}{|c|}{2017} & & \multicolumn{6}{|c|}{2018} \\
\hline & \multicolumn{5}{|c|}{ Days after storage } & & \multicolumn{6}{|c|}{ Days after storage } \\
\hline & 0 & $2^{\text {nd }}$ & $4^{\text {th }}$ & $6^{\text {th }}$ & $8^{\text {th }}$ & MEAN & 0 & $2^{\text {nd }}$ & $4^{\text {th }}$ & $6^{\text {th }}$ & $8^{\text {th }}$ & MEAN \\
\hline Control & 84.18 & 86.32 & 90.23 & 83.12 & 80.90 & 84.86 & 93.15 & 93.80 & 94.45 & 93.22 & 87.24 & 93.43 \\
\hline (SA,200 ppm) & 88.92 & 89.12 & 93.45 & 95.50 & 93.45 & 92.09 & 98.83 & 99.27 & 100.75 & 101.34 & 100.34 & 100.77 \\
\hline$(\mathrm{SA}, 400 \mathrm{ppm})$ & 92.45 & 92.89 & 97.22 & 99.32 & 97.33 & 95.84 & 100.52 & 100.90 & 101.22 & 102.10 & 101.45 & 102.05 \\
\hline (SA, 600 ppm) & 96.71 & 96.92 & 101.55 & 102.42 & 100.79 & 99.68 & 101.40 & 101.91 & 102.46 & 102.96 & 101.80 & 102.73 \\
\hline$(\mathrm{PG}, 150 \mathrm{ppm})$ & 86.45 & 87.12 & 91.40 & 92.68 & 88.42 & 89.25 & 95.52 & 96.40 & 96.87 & 98.22 & 97.75 & 97.26 \\
\hline$(\mathrm{PG}, 300 \mathrm{ppm})$ & 90.42 & 91.40 & 94.18 & 95.35 & 91.34 & 92.54 & 99.87 & 100.12 & 100.73 & 101.28 & 100.93 & 101.18 \\
\hline$(\mathrm{PG}, 450, \mathrm{ppm})$ & 94.51 & 94.88 & 99.34 & 101.63 & 99.85 & 97.95 & 100.88 & 101.44 & 102.20 & 102.80 & 101.50 & 102.38 \\
\hline MEAN & 90.52 & 91.23 & 95.37 & 95.65 & 93.09 & & 98.59 & 99.12 & 99.69 & 101.11 & 99.95 & \\
\hline \multirow[t]{3}{*}{ CD VALUE } & \multicolumn{4}{|c|}{ DAYS } & 0.573 & & & \multicolumn{4}{|c|}{ DAYS } & 0.585 \\
\hline & \multicolumn{4}{|c|}{ TREATMENT } & 0.484 & & & \multicolumn{4}{|c|}{ TREATMENT } & 0.494 \\
\hline & \multicolumn{4}{|c|}{ TREATMENT X DAYS } & 1.28 & & & \multicolumn{4}{|c|}{ TREATMENT X DAYS } & 1.308 \\
\hline
\end{tabular}


Int.J.Curr.Microbiol.App.Sci (2020) 9(4): 2914-2923

Table.4 Effect of salicylic acid and propyl gallate on total sugars content (\%) in ber fruits during storage

\begin{tabular}{|c|c|c|c|c|c|c|c|c|c|c|c|c|}
\hline \multicolumn{13}{|c|}{ Total sugar (\%) } \\
\hline \multirow[t]{3}{*}{ TREATMENT } & \multicolumn{5}{|c|}{2017} & & \multicolumn{6}{|c|}{2018} \\
\hline & \multicolumn{5}{|c|}{ Days after storage } & & \multicolumn{6}{|c|}{ Days after storage } \\
\hline & 0 & $2^{\text {nd }}$ & $4^{\text {th }}$ & $6^{\text {th }}$ & $8^{\text {th }}$ & MEAN & 0 & $2^{\text {nd }}$ & $4^{\text {th }}$ & $6^{\text {th }}$ & $8^{\text {th }}$ & MEAN \\
\hline Control & 9.32 & 9.80 & 10.54 & 9.80 & 9.51 & 9.80 & 9.65 & 10.22 & 10.75 & 10.40 & 10.04 & 10.21 \\
\hline (SA, 400 ppm) & 10.12 & 10.80 & 11.40 & 11.71 & 11.36 & 11.07 & 10.69 & 11.29 & 11.69 & 12.07 & 11.84 & 11.51 \\
\hline (SA, 600 ppm) & 10.99 & 11.52 & 11.87 & 12.55 & 12.16 & 11.81 & 11.48 & 11.78 & 12.23 & 13.04 & 12.61 & 12.22 \\
\hline (PG,150 ppm) & 9.48 & 10.12 & 10.61 & 11.19 & 10.53 & 10.38 & 9.84 & 10.47 & 10.99 & 11.38 & 10.92 & 10.72 \\
\hline$(\mathrm{PG}, 300$ ppm) & 19.94 & 10.60 & 11.27 & 11.44 & 11.06 & 10.86 & 10.35 & 10.94 & 11.46 & 11.84 & 11.44 & 11.20 \\
\hline$(\mathrm{PG}, 450, \mathrm{ppm})$ & 10.65 & 11.29 & 11.62 & 12.17 & 11.75 & 11.49 & 11.20 & 11.49 & 11.94 & 12.62 & 12.22 & 11.89 \\
\hline MEAN & 10.03 & 10.63 & 11.16 & 11.45 & 10.99 & & 10.46 & 10.97 & 11.46 & 11.84 & 11.43 & \\
\hline \multirow[t]{3}{*}{ CD VALUE } & \multicolumn{4}{|c|}{ DAYS } & 0.521 & & & \multicolumn{4}{|c|}{ DAYS } & 0.851 \\
\hline & \multicolumn{4}{|c|}{ TREATMENT } & 0.440 & & & \multicolumn{4}{|c|}{ TREATMENT } & 0.721 \\
\hline & \multicolumn{4}{|c|}{ TREATMENT X DAYS } & N/A & & & \multicolumn{4}{|c|}{ TREATMENT X DAYS } & N/A \\
\hline
\end{tabular}


The fruits show the higher vitamin C (99.68 and $102.72 \mathrm{mg} / 100 \mathrm{~g}$ ) under SA @600 ppm as compared to other treatments while minimum in control $(84.86$ and $93.43 \mathrm{mg} / 100 \mathrm{~g})$ in both years respectively. It is obvious from the data that increase in vitamin $\mathrm{C}$ content of ber fruits coincided with ripening process being maximum on $6^{\text {th }}$ day of storage.

However, there was decline in ascorbic acid content of fruits at further enhancement in storage period. The delay in attainment of the maximum ascorbic acid content might be due to delayed ripening process in response to the treatment of the SA and PG the gradual increase in ascorbic acid content in ber fruits might be owing to fact that during ripening stages ascorbic acid was synthetized from uronic acid a component of pectin degradation (Hegedüs et al., 2011). SA treated fruit might have delayed pectin degradation by inactivating cell wall degrading enzymes ( $\mathrm{Li}$ and Han 1999; Srivastava and Dwivedi, 2000). Shirazadeh and Kazemi (2012) reported that SA had significant effect on apple. Shafiee et al., (2010) revealed ascorbic acid delayed strawberry and similar finding were found in pineapple fruits (Lu et al., 2011).

Statistically significant results were found at $\mathrm{p} \leq 0.05$ regarding the effects of treatments, storage periods and their interaction on total sugar content Table 4 . The higher sugar found in (11.81 and $12.22 \%)$ under SA @ 600 ppm in two years while minimum in control $(9.80$ and $10.21 \%$ ) in two years respectively.

Total sugars showed an increasing trend up to storage in all the treated fruits except in control, but decreased after $6^{\text {th }}$ day of storage. Similar results were also reported by Jayachandran et al., (2005) in guava fruits. The increase in sugar content might be due to conversion of certain cell wall materials like pectin and hemicellulose into reducing substances during storage (Stahl and Camp, 1971). The increase in soluble sugar might be owing to action of sucrose phosphate synthases (SPS) resulted in the sucrose biosynthesis. The increased sucrose phosphate synthase increased activity in invertase enzyme and decreased activity of sucrose synthase as reported Cordenunsi and Laljolo (1995). These results agreed with findings of Hubbard et al., (1991) in strawberry fruits and longan fruits. Similar results were also reported by Sayari et al., (2009) postharvest management of pomegranate fruit treated SA.

Overall the results indicated that $\mathrm{cv}$ of ber Banarasi Karaka remained in better conditions after 6day of storage at room temperature. SA @ 600 ppm effective in minimize loss of firmness, colour change and respiration rate and ethylene production rate, which helped in improving the shelf-life and maintained the quality of ber fruits during storage. Plant growth regulators are good prospective to increase productivity of fruits by bringing out a change in hormonal status of the plant which provide significant advantage to the growers. Exogenous application of Salicylic Acid at nontoxic concentration of susceptible fruit could enhance resistant to pathogen and control postharvest decay.

\section{References}

A.O.A.C. (1980). Official methods of analysis of analytical chemists. Association of the Official Analytical Chemists, Washington, D.C.

Anon (1976). In: Karnataka Statistics, Department of Horticulture Govt of India 1.

Bailey L. H. (1947). The standard cyclopaedia of horticulture. New York: Macmillan and Company

Bal J. S. (1981). A note on sugars and amino acids in ripe ber. Progressive Horticulture, 13 (3/4): 41-42. Bal, J. S., Ranadhava, J. S. (2005). Studies on the 
preparation of various products from the fruits. International Journal of Agricultural Sciences, 1(1): 56-57

Bal J. S. Singh, P. and Singh, R. (1978). Preliminary observations on the storage behavior of ber at room and refrigerated temperature. Punjab Agriculture University Research Journal., Ludhiana 25: 396-399.

Chen F., D Auria J. C., Tholl D., Ross J. R., Gershenzon J., Notel J. P. and Pichersky, E (2003) An Arabidopsis thaliana gene for met salicylate biosynthesis, identified by biochemical genomics approach, has a role in defense. The Plant Journal 36:577- 588 .

Cordenunsi R. R., and Lajolo F. M. (1995). Starch breakdown during banana ripening. Sucrose synthase and sucrose phosphate synthase. Journal of Agricultural and Food Chemistry, 43: 347-351.

Dalal N., Neeraj and Bisht V. (2019)- Value added products from ber. International Journal of Current Microbiology and Applied Sciences, 8(1): 1603-1615.

Dastjerdi A., Moradi N., Rezazadeh E.and Heidari M(2014). Effect of salicylic acid and storage time on quality of mango fruits (Mangifera indica L.). 27-36.

Fariduddin Q., Hayat. and Ahmad A (2003) salicylic acid influences net photosynthetic rate, carboxylation efficiency, nitrate reductase activity and seed yield in Brassica juncea, Photosynthetica 41:281-284.

Han T and Li L P. (1997). Physiological effect of salicylic acid on storage of apple in short period. Plant Physiology Communications 33: 347-48.

Hegedűs A., Pfeiffer P., Papp N., Abrankó L., Blázovics A., Pedryc A. and Bányai É. S. (2011 Accumulation of antioxidants in apricot fruit through ripening: characterization of a genotype with enhanced functional properties. Biological Research, 44: 339-344.

Hubbard N. L., Pharr D. M., and Huber S. C. (1991). Sucrose phosphate synthase and other sucrose metabolizing enzyme in fruits of various species. Plant Physiology, 106:605-175.

Islam M. B. and Simmons M.P. (2006). A thorny dilemma: testing alternative intragenic classifications with in Ziziphus (Rhamnaceae). Systematic. Botany, 31:826-842.

Jawanda J. S., Bal J. S., Josan J. S. and Mann S. S. (1980). Studies on storage of ber fruit II. Cool temperature. Punjab Horticultural Journal, 20: 56-61.

Jayachandran K. S., Srihari D. and Reddy Y. N. (2005). Pre-harvest sprays of different sources of calcium to improve the shelflife of guava. Indian Journal of Horticulture. Science., 62: 68-70.

Karlidag H., Yildirim E. andTuran M. (2009). Salicylic acid ameliorates the adverse effect of salt stress on strawberry. Journal of Agricultural Sciences, 66:271278.

Langenkamper G., Mc-Hale R., Gardne R. C. and MacRao E. (1998). Sucrose phosphate synthase steady -state mRNA increases in ripening kiwifruit. Plant Molecular Biology, 36:857-869.

Lee HI and Raskin, I (1999) Purification, cloning and expression of a pathogen inducible glucose: salicylic acid glucosyl transferase from tobacco. Journal of Biological Chemistry. 274: 3663-3664.

Lu X., D. Sun Y. Li W. Shi and G. Sun (2011). Pre- and Post- harvest salicylic acid treatments alleviate internal browning and maintain quality of winter pineapple fruit. Scientia Horticulturae: 130: 97-101.

Madhav J. V., Sethi S., Sharma R. R., and Nagaraja, A. (2018) -Impact of Salicylic Acid Treatments on Storage Quality of Guava Fruits cv. Lalit during Storage. International Journal of Current Microbiology and Applied Sciences. 7(9): 2390-2397.

Park S. W., Kaimoyo E., Kumar D., Mosher S. and Klessing D. F. (2007) Methyl salicylicate is a critical mobile signal for plant systemic acquired resistance, Sciences, 103-1111-1120. 
Pool K. M., Weaver R.J. and Kliewer K. M. (1972). The effect of growth regulators on changes in fruits of Thompson Seedless during cold storage. Journal of the American Society for Horticulture Science, 97: 67-70.

Salunkhe D. K., and Kadam S. S. (1995). Handbook of fruit science and technology Production, composition, storage and processing. Marcel Dekker, New York.

Sandbhor D. R. and Desai U. T. (1991). Influence of postharvest treatment on the shelf life of ber (Zizyphus mauritiana Lamk.) cv. Umran. Mah. J. Hort., 5: 2428.

Sayyari M., M. Babalar S., Kalantari M., Serrano and Valero D.(2009). Effect of salicylic acid treatment on reducing chilling injury in stored pomegranates, Postharvest Biology and Technology., 53: $152-154$

Shafiee M., Taghavi T. S. and Babalar M. (2010). Addition of salicylic acid to nutrient solution combined with postharvest treatments (hot water, salicylic acid, and calcium dipping) improved postharvest fruit quality of strawberry. Scientia Horticulture, 124: 40- 45.

Shirzadeh E. and Kazemi M. (2012). Effect of salicylic acid and essential oils treatments on quality characteristics of apple (Malus domestica Var. Granny Smith) fruits during storage. Asian Journal of Biochemistry, 7(3): 165-170.

Shulaev V., Silverman P., and Raskin I. (1997)
Airborne signaling by methyl salicylate in plant pathogen resistance, Nature. 385:718-721.

Song J.T., Lu H. and Greenberg J. T. (2004). Divergent role in Araabidioaopsis thalinana development and defense of homologous gene, Aberrant Growth and Death2 Agd2-Like Defense Response Protein encoding novel amino transferase. The Plant Cell. 16:353-366.

Srivastava M. K. and Diwedi U. N. (2000)Delayed ripening of banana fruit by salicylic acid. Plant Science 158, 87-96.

Stahl A. C. and Camp A. F. (1971). Citrus fruits. In The Biochemistry of Fruits and their Products (Ed., Hulme A C). 2: 107169.

Vlot A. C., Liu P. P., Cameron R. K et al (2008) identification of likely orthologs of tobacco salicylic acid binding protein 2and their role in systemic acquired resistance in Arabidiopsis thaliana. The Plant Journal. 56:445-456.

Wills R. B. H., Babmbridge P. A. and Scott,K. J. (1980). Use of flesh firmness and their objectives tests to determine the consumer acceptability of Delicious apple. Australian Journal of Experimental Agriculture and Animal Husbandry, 20: 252-256.

Zhang Y., K. Chen S. Zhang and Ferguson I. (2003). The role of salicylic acid in postharvest ripening of kiwifruit, Postharvest Biology and Technology, 28 (1): 67-74.

\section{How to cite this article:}

Deepti Shrivastva, Akhilesh Kumar Pal, Surendra Prasad Singh and Kalyan Barman. 2020. PreHarvest Application of Salicylic Acid and Propyl Gallate to Preserve Postharvest Quality of Ber (Ziziphus maurtiana Lamk) Fruits cv Banarasi Karaka. Int.J.Curr.Microbiol.App.Sci. 9(04): 2914-2923. doi: https://doi.org/10.20546/ijcmas.2020.904.341 